\title{
Angiogenesis Inhibitory Protein
}

National Cancer Institute

\section{Source}

National Cancer Institute. Angiogenesis Inhibitory Protein. NCI Thesaurus. Code C18582.

A protein that prevents the formation of new blood vessels. 